\title{
Arktik Bölge'de Uluslararası Siyasi Düzen: Teorik Bir Yaklaşım
}

\author{
International Political Order of the Arctic: A Theoretical Approach
}

Hasan Fatih SEVAL ${ }^{1}$

Geliş tarihi: 31.05.2019, Kabul tarihi: 26.07.2019, Basım tarihi: 25.10.2019

\section{Öz}

Küresel ısınmanın etkilerinin daha belirgin bir şekilde hissedilmeye başlandığı son yıllarda Arktik Bölge, sadece iklimsel konularda değil, siyasi konularda da ön plana çıkmaya başlamışır. Buzul kütlelerinin erimesiyle bölgeye erişim kolaylaşmış; zengin doğal kaynak potansiyeli ve yeni ticaret yollarının kullanım ihtimali bölgeyi küresel bir coğrafya haline dönüştürmüştür. Küresel ölçekte stratejik öneme sahip olan bölgede, Soğuk Savaş'tan bu yana istikrarlı bir uluslararası politik düzen hâkimdir. Çıkar çatışmaları ihtimalinin artacağı öngörülen önümüzdeki yıllarda bu istikrarın sürdürülebilmesi için, bölgeye hâkim uluslararası siyasi düzenin doğasını anlamak önemlidir. Çalışmada, öncelikle Uluslararası İlişkiler disiplininde tanımlandığ1 şekliyle istikrarlı bir düzen olup olmadığı sorgulanmış, ardından bölgedeki uluslararası düzen üç farklı teorik yaklaşım bağlamında ele alınmıştır.

Anahtar Kelimeler: Arktik Bölge, Uluslararası Düzen, İstikrar

JEL kodlar1: F02, F50, Q34

\begin{abstract}
In recent years, as the effects of global warming have become more apparent, the Arctic has begun to come into prominence not only on climatic issues but also on political issues. With the melting of glacial masses, access to the area was facilitated; the rich natural resource potential and the possibility of using new trade routes have transformed the region into a global geography. In the Arctic, which has strategic importance on the global scale, a stable international political order has prevailed since the Cold War. It is important to understand the nature of the international political order that dominates the region in order to maintain this stability in the coming years, where the possibility of conflicts of interest is expected to increase. In this paper, firstly, it is questioned whether there is a stable order as defined in the International Relations discipline; and then the international order in the region is discussed in the context of three different theoretical approaches.
\end{abstract}

Keywords: The Arctic, International Order, Stability

JEL codes: F02, F50, Q34

\footnotetext{
${ }^{1}$ Burdur Mehmet Akif Ersoy Üniversitesi, İIBF, Uluslararası İlişkiler Bölümü, Arş.Gör. hfseval@mehmetakif.edu.tr https://orcid.org/0000-0003-4609-8819
} 


\section{Giriş}

Son çeyrek yüzyılda Arktik Bölge ${ }^{2}$, pek çok farklı özelliği sebebiyle birbirinden farklı alanlardan bilim insanlarının dikkatini cezbetmeye başlamıştır. Hem gelişen teknolojiyle birlikte bölgeye ulaşım imkânlarının artması hem de küresel isınmanın sonucu olarak buzulların hatırı sayllır seviyede erimesi sebebiyle Arktika, antropologlar, biyologlar ve çevrebilimciler başta olmak üzere pek çok araştırmacı için bâkir ve çalışılmamış bir alan olarak ortaya çıkmıștır. Tüm bunlarla birlikte Arktika, zengin doğal kaynak rezervleri ve stratejik konumu dolayısıyla Uluslararası İlişkiler disiplini için de önemli bir bölge hüviyetine sahiptir.

Gerek stratejik konumundan ötürü kitalar arası ticarette yeni rotaların kullanımına imkân sağlaması bakımından, gerekse büyük yeraltı zenginliği bakımından '21. yüzyılın coğrafi keşifleri' olarak da adlandırılabilecek Arktik araştırmalarına göre, bölge, önümüzdeki yıllarda küresel siyasetin merkezlerinden biri olma potansiyeline sahiptir. Bu sebeple, küresel etkilere sahip olan Arktik Bölge'de siyasi düzen, Uluslararası İlişkiler disiplini için oldukça mühim bir konu olarak öne çıkmaktadır. Soğuk Savaş'in sona ermesinden itibaren siyasi bir istikrarın gözlemlendiği bölgedeki uluslararası siyasi düzenin doğasını anlamak, küresel 1sınmanın etkileriyle bölgeye ve bölge kaynaklarına erişimin kolaylaşacağı, dolayısıyla çıkar çatışması ihtimallerinin artacağı önümüzdeki yllarda bölge ile ilgili yaklaşımları şekillendirme açısından önemlidir.

Çalışmada ilk olarak Arktik Bölge'nin tam olarak nereyi ifade ettiği, küresel önemi ve etkili aktörleri ele alınmıştır. Ardından bölgedeki uluslararası düzenin doğası Uluslararası İlişkiler literatürü çerçevesinde tartışılmış ve bölgede istikrarın hâkim olduğu ortaya koyulmuştur. Son olarak, bölgede hâkim olan istikrarlı uluslararası düzenin, Uluslararası İlişkiler disiplininin Çok Kutuplu İstikrar, Hegemonik İstikrar ve Demokratik Barış Teorisi yaklaşımlarından hangisiyle daha iyi bir şekilde açıklanabileceği tartışılmıştır.

\section{Arktik Bölge}

\subsection{Bölgenin Tanımı}

Genel itibariyle Kuzey Kutbu ve çevresini niteleyen Arktik Bölge ile ilgili tam anlamıla fikir birliğine varılmıs bir sınır tanımlaması yoktur. Bölgeyle ilgili coğrafya, iklim, biyolojik çeşitlilik ve demografik özellikler gibi faktörleri baz alarak yapılan tanımlamalarla birlikte, doğal olarak, siyasi alan tanımlamaları da vardır. Örneğin, bölgedeki en önemli uluslararası örgütlerden biri olan Arktik Konsey'in desteklediği projelerden Circumpolar

\footnotetext{
2 Çalışma boyunca ilgili bölgeden bahsederken, aynı ifadeleri sık sık kullanarak bir kakofoni oluşturmaktan kaçınma endişesiyle, zaman zaman 'Arktika' ifadesi de kullanılmıştır.
} 
Arctic Vegetation Map'e (CAVM) ${ }^{3}$ göre Arktik Bölge yaklaşık 7,1 milyon $\mathrm{km}^{2}$ lik bir alanı ifade etmektedir (Conservation of Arctic Flora and Fauna (CAFF), 2013: 14). Yine Arktik Konsey'in alt oluşumlarından biri olan Arktik İzleme ve Değerlendirme Programı'na (Arctic Monitoring and Assessment Programme [AMAP]) göre ise bölgenin daha geniş bir alan tanımı vardır. Arktika'nın sınırları üzerinde belli bir fikir birliği olmadığı için, bölge nüfusu da yapılan tanımlamaya göre 4 ile 10 milyon arasında değişiklik göstermektedir (Ahlenius vd., 2005: 14; Duhaime ve Caron, 2006: 9; Heleniak, 2014: 53). Çalışmada, Harita 1'de kırmızı çizgiyle gösterilen, Kuzey Kutup Dairesi içerisinde kalan tüm alanı, Arktik Okyanusu'nun Atlantik ve Pasifik okyanuslarıyla bağlantılarını ve Sibirya ve Kuzey Amerika'nın Arktika'ya bakan kıyılarını kapsayan AMAP'ın Arktik Bölge tanımlaması baz alınmıştır.

\section{Harita 1. Arktik Bölge}

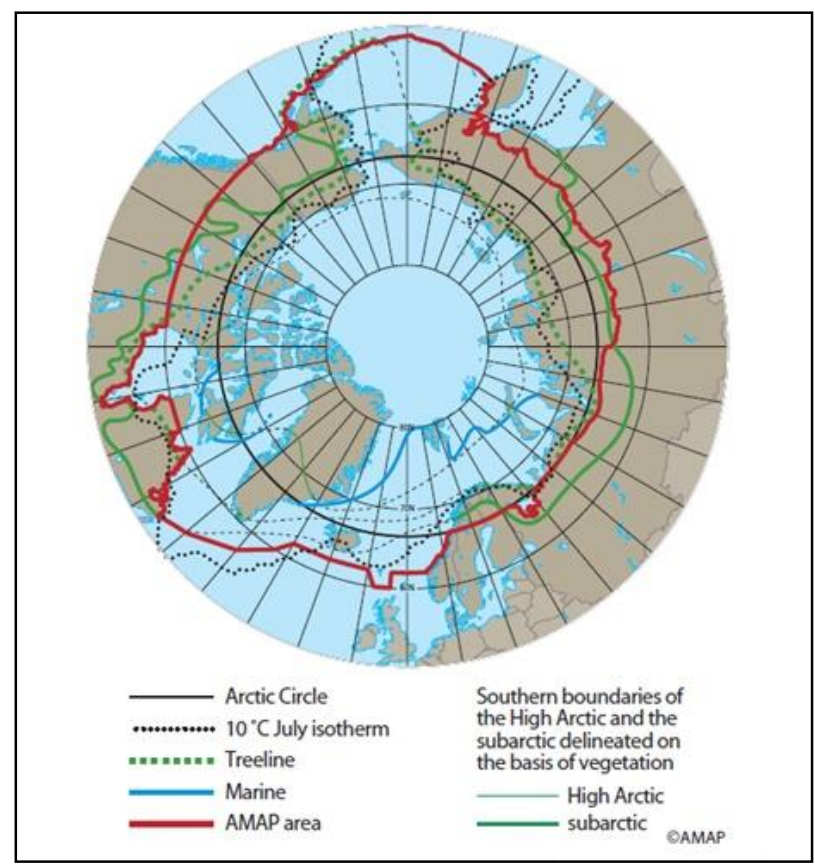

Kaynak: Arctic Monitoring and Assessment Programme (AMAP), 2010

\subsection{Bölgenin Küresel Önemi}

Arktika, iklimsel şartları dolayısıyla insan yaşamı için elverişli koşullara sahip olmayan, haritaya bakıldığında sadece kıyıdaş 8 ülkeyi ilgilendiren

\footnotetext{
3 CAVM, Arktik bölgenin bitki örtüsü ile ilgili özelliklerini haritalandıran uluslararası bir projedir. Bölgeyi ekolojik bir perspektifle tanımlar. Coğrafyada 'ağaç sınırı' olarak adlandırılan ve yllın en sıcak döneminde dahi $10-12^{\circ} \mathrm{C}^{\prime}$ nin altında kalan bölgeyi Arktika olarak tanımlar.
} 
kapalı bir bölge gibi görünüyor olsa da, gerçekte durum daha farklıdır. Özellikle küresel ısınmanın etkisiyle, bölgeye hâkim olan buz kütlesi zamanla incelmeye ve yer yer yok olmaya başlamıştır. İklim değişikliğinin etkilerinin en bariz şekilde görüldüğü bölge olan Arktika'da son bir asırda sıcakliklar, küresel sıcaklığın artış oranının neredeyse iki katı oranında yükselmiştir. $\mathrm{Bu}$ yüksek orandaki değişimin, 30 yil gibi bir süre içinde Arktika'daki tüm buzulların erimesine yol açacağını öngören çalışmalar mevcuttur (Ecorys Research Programme, 2014: 5-6).

Küresel ısınmanın etkisiyle Arktika buzullarının erimesinin, birden çok boyutuyla küresel etkileri vardır. Bunların başında, buzulların erimesi sonucunda deniz seviyesinin yükselmesi gelmektedir. Yapılan çalışmalarda, Arktik Bölge'deki buzulların tamamının erimesi halinde deniz seviyesinin ortalama 7 metreden daha fazla yükseleceği ve bu durumun pek çok kıyı yerleşimini olumsuz etkileyeceği belirtilmiştir (Ross, 2014: 144).

Buzulların erimesinin bir diğer sonucu, bölgenin kıtalararası ticarette yeni bir rota olarak kullanılabilecek oluşudur. Harita 2'de Avrupa ile Asya ve Batı Amerika arasındaki hal-i hazırda kullanılan güzergâhlar (siyah çizgi) ve Arktika üzerinden kullanılabilecek alternatif güzergâhlar (kırmızı kesikli çizgi) gösterilmektedir. Kuzeybatı Geçidi’nin (solda) kullanılması halinde, Kuzey Amerika'nın batısı ile Avrupa arasındaki mesafe, Panama Kanalı üzerinden giden mevcut rotaya nazaran 7 bin kilometre daha kısa olacaktır (Mundy, 2016: 156). Kuzey Denizi Güzergâhı (sağda) ise Avrupa ile Kuzeydoğu Asya arasındaki mesafeyi, Süveyş Kanalı'ndan geçen güzergâha nispeten yaklaşık \% 40 oranında düşürecektir (Bekkers vd., 2015: 10). Bu iki Arktik rota, nakliye şirketlerinin Süveyş ve Panama kanallarındaki artan geçiş ücretlerinden (Jervis, 2016) kaçınmasına ve daha büyük hacimlerde yük taşıma kapasitesine sahip olan gemiler kullanmasına olanak sağlayabilir. Yeni rotaların avantajlarından bir diğeri ise Ortadoğu'daki politik açıdan istikrarsız bölgelerden ve korsancilık faaliyetlerinin bulunduğu sulardan daha güvenli bir geçit olmasıdır (Nong vd., 2018). Sonuçta Arktik Bölge, kıtalararası ticarette kullanılabilecek alternatif rotalar sağlaması bakımından da küresel öneme sahip bir bölge olarak karşımıza çıkmaktadır. Ancak, günümüzde Arktik rotaların kullanımının, iklimsel şartlardan dolayı hâlâ oldukça zorlu olduğu da belirtilmelidir. 


\section{Harita 2. Ticaret Rotalar1}

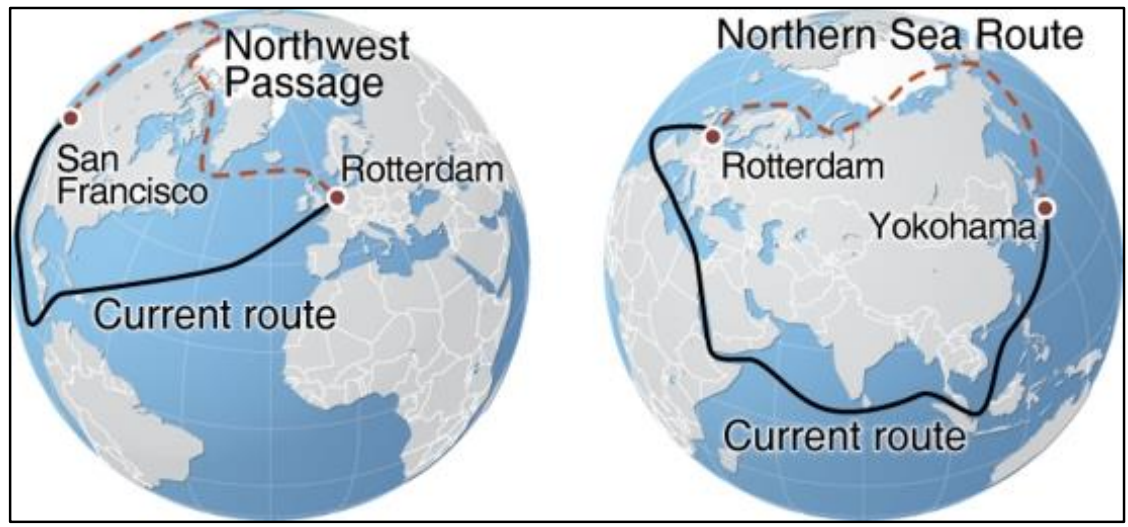

Kaynak: Ahlenius, 2007

Arktik buzulların erimesinin en yüksek stratejik öneme sahip sonuçlarından birisi, belki de en önemlisi, bölgedeki yeraltı kaynaklarına erişimin kolaylaşacak olmasıdır. Bölgede henüz keşfedilmemiş 90 milyar varil petrol olduğu tahmin edilmektedir. Bu miktar, dünyanın toplam petrol rezervinin \% 6'sına denk gelmektedir. Dünya petrol rezervinin \% 5'ine Rusya'nın, \% 2'sine de ABD'nin sahip olduğu düşünüldüğünde, bölgenin potansiyeli daha belirgin olarak karşımıza çıkmaktadır. Doğalgaz konusunda ise potansiyel daha da yüksektir: Arktika, dünyadaki bilinen rezervlerin yaklaşık dörtte birine sahiptir. Bu potansiyel, ABD rezervlerinin yaklaşık 5 katına tekabül etmektedir. Bölge, aynı zamanda altın, elmas, bakır, demir, çinko ve uranyum gibi metal ve mineral kaynakları açısından da oldukça zengindir (Desjardins, 2016; Perry ve Andersen, 2012: 13; Lindholt, 2006). Fakat bölgedeki yeraltı kaynaklarına erişim, hâlâ zorlayıcı iklimsel ve coğrafî koşullar sebebiyle oldukça yüksek maliyetlidir.

\subsection{Arktik Aktörler}

AMAP'ın bölge tanımlamasında toprakları bulunan sekiz ülke, aynı zamanda Arktik Konsey'i de oluşturmaktadır. Arktik Konsey, özellikle sürdürülebilir kalkınma ve doğanın korunması hususları çerçevesinde Arktik ülkeleri ve bölgede bulunan yerli topluluklar arasında işbirliği, koordinasyon ve etkileşimi teşvik eden bir hükümetler-arası örgüttür. 1996 Ottawa Deklarasyonu'nda Kanada, Danimarka, Finlandiya, İzlanda, Norveç, Rusya Federasyonu, İsveç ve Amerika Birleşik Devletleri (ABD) Arktik Konsey’in üye ülkeleri olarak belirlenmiştir. Bu sekiz ülkenin yanında, bölgede yaşamlarını sürdüren yerli halkları temsil eden altı örgüt ${ }^{4}$, Daimi Katılımcılar

4 Daimi Katılımcı statüsündeki örgütler vasıtasıyla temsil edilen yerel halklar, Aleutlar (Unanganlar), Atabasklar (Deneler), Guçinler, İnuitler, Samiler (Laponlar) ve Kuzey Rusya Yerlileri'dir. 
statüsündedir. Bunlarla birlikte, 13 Arktika-dışı ülke Arktik Konsey'de gözlemci ${ }^{5}$ statüsüne sahiptir. Arktik Konsey, Çalışma Gruplar1 ${ }^{6}$ aracilığılla düzenli bir şekilde kapsamlı ekolojik ve sosyal projelerin üretilmesine olanak sağlamış; ayrıca sekiz üye ülke arasında üç önemli yasal bağlayıcı anlaşmanın ${ }^{7}$ imzalanması sürecinde önemli katkılarda bulunmuştur. Bunlara rağmen Arktik Konsey, bir hükümetler-arası forumdur ve bütçesi yoktur. Tüm projeler üye veya gözlemci ülke(ler) tarafindan desteklenmektedir. Arktik Konsey'in yönergelerini, değerlendirmelerini veya önerilerini uygulayıp uygulamamak konusunda tercih, üyelerin kendi sorumluluklarındadır; Konsey'in herhangi bir yaptırım gücü yoktur. Ayrıca, Ottawa Deklarasyonu'nda açıkça belirtildiği gibi, askerî güvenlik konuları Arktik Konsey'in kapsamı dışında kalmaktadır (Arctic Council, 2018).

Arktika'daki bir diğer önemli uluslararası örgüt, Arktik Okyanus'a kıyısı bulunan beş ülkenin ${ }^{8}$ oluşturduğu Arktik Beşli'dir. Arktik Beşli'nin, onu oluşturan devletler dışında bağımsız bir gücünün veya varlığının olmadığı vurgulanmalıdır. Arktik Beşli kavramı, resmî bir isim olmaktan ziyade, Arktik Okyanus'a kıyısı olan ülkeler arasındaki etkileşimi, işbirliğini, görüşmeleri ve organizasyonları nitelendirmek üzere kullanılır. Yine de bu oluşumun tamamen önemsiz olduğu da söylenemez. Söz konusu devletler arasında gerçekleştirilen toplantılar ve ortaya çıkan projeler, bölge açısından öneme sahiptir. Bölgeyle ilgili ortak karar alınması gereken konularda bir forum işlevi gören en önemli Arktik Beşli toplantıları 2008 yllında Danimarka'da, 2010 yllinda Kanada'da ve 2015 yilında Norveç'te düzenlenmiştir (Kuersten, 2016: 435).

Görüldüğ̈̈ üzere, Arktik Konsey ve Arktik Beşli, bölgeyle ilgili ekolojik ve demografik çalışmalarda işbirliğine odaklanmış yapılar olsa da, birtakım siyasî ve hukukî anlaşmalara varılması süreçlerinde de katkılarda bulunmuştur. Bununla birlikte, Arktik Konsey'e üye ülkelerin tamamının Birleşmiş Milletler (BM), üçünün Avrupa Birliği $(\mathrm{AB})$ ve dördünün Kuzey Atlantik Antlaşması Örgütü (NATO) üyesi olmaları, adı geçen uluslararası organizasyonların da dolaylı olarak Arktika siyasi düzeninde etkili aktörler olarak öne çıkmasını sağlamaktadır. Özellikle BM, bölge ilişkilerini düzenleyen en önemli hukukî anlaşma olan BM Deniz Hukuku Sözleşmesi dolayısıyla, bölge ilişkilerinde düzen sağlayıcı örgütlerin başında gelmektedir.

\footnotetext{
5 Arktik Konsey'de gözlemci statüsüne sahip ülkeler Fransa, Almanya, İtalya, Japonya, Hollanda, Çin Halk Cumhuriyeti, Polonya, Hindistan, Güney Kore, Singapur, İspanya, İsviçre ve İngiltere'dir.

6 Arktik Konsey'in altı çalışma grubunun tamamı bölgeyle ilgili ekolojik, biyolojik ve demografik araştırmalarla ilgilidir.

7 Arktik Arama ve Kurtarma Sözleşmesi (2011), Arktika'da Deniz Petrol Kirliliğine Hazırlıklı Olma ve Müdahale Konusunda İşbirliği Anlaşması (2013), Uluslararası Arktik Bilimsel İşbirliğini Artırma Anlaşması (2017)

${ }^{8}$ ABD, Kanada, Rusya, Norveç ve Danimarka
} 
$\mathrm{Bu}$ noktada akla gelen sorulardan biri, Arktik Bölge'deki düzenin ne şekilde açılanabileceği konusundadır: kargaşa mı, yoksa istikrar mı? Yukarıda da görüldüğü üzere, bölgede farklı düzeylerde (ulus-altı örgütler, ulus-devletler, uluslararası ve uluslar-üstü yapılanmalar) çok sayıda aktör etkindir. Küresel 1sınmanın etkisiyle buzulların azalması sonucunda bölge, zengin yeraltı kaynakları potansiyeli ve alternatif ticaret güzergâhları sunması dolayısıyla, sadece Arktik ülkeler için değil, başta Çin olmak üzere Arktikadışı ancak dış kaynaklara bağımlı aktörler için de giderek daha önemli bir konuma yükselmektedir. $\mathrm{Bu}$ durum, şüphesiz, bölge ilişkilerini karmaşıklaştıran bir olgudur. Öte yandan, özellikle hukukî bağlamda bölge ilişkilerini düzenleyici anlaşmaların mevcut olması, ihtilaflı konuların hukuka başvurularak çözüme kavuşturulması ve bölgenin herhangi bir sıcak çatışmaya sahne olmaması, istikrar ve düzen fikirlerini güçlendiren olgulardır. Yine de bölge ilişkilerinde kargaşanın mı yoksa istikrarın hâkim olduğunu belirleyebilmek için, öncelikle Uluslararası İlişkiler disiplininde ‘düzen' kavramının nasıl tanımlandığını görmek, ardından bölge aktörlerini ve aralarındaki ilişkilerin dinamiklerini daha ayrıntılı ele almak gereklidir.

\section{Arktik Bölge'de Uluslararası Düzen}

\subsection{Uluslararası İlişkilerde 'Düzen' Kavramı}

Kelime anlamı "belli yöntem, ilke veya yasalara göre kurulmus olan durum, uyum, niz̧am, sistem" (Türk Dil Kurumu, t.y.) olan düzen, Uluslararası İlişkiler disiplininin temel kavramlarından biridir. Disiplinin ilk yıllarına hâkim olan ana-akım teorilerin uluslararası düzen yaklaşımı, 'anarşi' çerçevesinde olmuştur. Öyle ki, disiplinin ilk büyük tartısmasının taraflarını oluşturan İdealistler (Liberaller) de Realistler de kuramlarını, uluslararası sistemin anarşik doğası üzerine inşa etmişlerdir. Liberaller ve Realistler, en basit ifadelerle "devletleraras iliskileri düzenleyip denetleyecek bir üst otoritenin olmamast durumu" şeklinde tanımlanabilecek anarşinin varlığını kabul etmekle birlikte, bu olguya yaklaşımları bakımından ayrışmaktadır. Realistler anarşik uluslararası sistemi sürekli bir savaş hâli ${ }^{9}$ olarak görürken; Liberaller anarşik ortama rağmen devletlerarası işbirliğinin mümkün olabileceğini (Axelrod ve Keohane, 1985) savunur. Ancak, oldukça indirgemeci olan bu yaklaşımların, uluslararası ilişkilerin doğasını anlama ve anlatma konusunda yetersiz kaldığı, özellikle Soğuk Savaş'ın sonlarına doğru anlaşılmaya başlanmıştır.

Soğuk Savaş'in iki kutbu arasındaki gerilimin en yoğun olduğu dönemlerde Uluslararası İlişkiler disiplinine hâkim olan ve büyük ölçüde

\footnotetext{
9 Realist geleneğin önemli kaynaklarından biri olan Leviathan'ın 13. bölümünde Thomas Hobbes, doğa durumunda yaşayan insanların birbirlerine karşı sürekli bir savaş hâlinde olduğunu ifade eder (Leviathan'ın ilgili bölümünün detaylı analizi için bkz: Kavka, 1983). Buradan yola çıkan Waltz (1979: 88), bir dünya hükümetinin olmadığı uluslararası sistemde devletlerin, aynı doğa durumunda yaşayan insanlar gibi, çatışma ortamında varlıklarını sürdürdüğünü belirtir.
} 
maddi güç odaklı ana-akım teorilerin söylemlerine karşı, Soğuk Savaş'taki yumuşama döneminin ve başta sosyoloji olmak üzere diğer disiplinlerin Uluslararası İlişkiler çalışmalarına dahlinin de etkisiyle birlikte, özellikle 1970’li ylllardan itibaren disiplin içinde çeşitli konularda itirazlar yükselmeye başlamıştır. Bu itirazlar, genel olarak, maddi güç odaklı açıklamaların çoğu zaman yetersiz kaldığı, devletlerarası ilişkilerin askerî ve iktisadî boyutlarından başka boyutlarının da olduğu yönündedir. Ana-akım teorilerin anarşik uluslararası düzen anlayışına karşı en büyük meydan okumalardan biri İngiliz Okulu tarafından gelmiştir. İngiliz Okulu'nun Uluslararası İlişkiler disiplinine yaptığı katkıların başında gelen 'uluslararası toplum' yaklaşımı, anarşinin varlığın kabul etmekle birlikte, anarşinin bir 'kaos' durumu olmadığını belirterek, çatışma ve uzlaşmanın aynı anda var olabildiği, "anarşi içinde düzen" ş̧eklinde tanımlanabilecek yeni bir bakış açısı ortaya koymuştur (Jorgensen, 2015: 196).

İngiliz Okulu'nun önemli temsilcilerinden Hedley Bull'un The Anarchical Society isimli kitabının üç temel sorusundan biri, "dünya siyasetinde düzen nedir?" sorusudur (Bull, 2002: xxxii). Bull'a göre uluslararası düzen, "devletter toplumunun ya da uluslararası toplumun temel amaglarm destekleyen bir faaliyet örüntïsü"dür. Bull'un bahsettiği temel amaçlardan birincisi, sistemin ya da devletler toplumunun kendisinin muhafaza edilmesidir. Aralarındaki anlaşmazlıklar ne olursa olsun, bütün modern devletlerin üzerinde mutabık kaldıkları husus, kendilerinin uluslararası ilişkilerde temel aktör oldukları ve bu düzenin devamının sağlanması gerektiğidir. İkinci temel amaç, tüm devletlerin bağımsızlkklarını ve egemenliklerini sürdürmesidir. Bull'a göre bir devletin uluslararası topluma katıllımdan temel beklentisi, bağımsızlı̆ının ve egemenliğinin diğer devletler tarafindan tanınmasıdır. Buna karşlık kendisi de diğer devletlerin bağımsızlık ve egemenliklerini tanıyacağından ötürü, karşılıklı bir şekilde tanınma ve haklara riayet ortamı oluşacaktır. Temel amaçların üçüncüsü ise barıştır. Ancak Bull'un barıştan kastı, evrensel ve kalıcı bir barış ortamından ziyade, üye devletler arasında bir 'savaşsızlık' ortamının sağlanmasıdır (Bull, 2002: 8-18). Kısaca özetlemek gerekirse, Bull'a göre uluslararası hukuka riayet edilerek devletlerin egemenlik haklarının korunup anlaşmaların garanti altına alındığı ve şiddetin sınırlandırıldığı bir ortam, istikrarlı bir uluslararası düzene işaret eder.

Sosyal düzen konusunda çalışmalar yapmış ve sosyolojik yaklaşımdan yararlanmış siyaset bilimcilerden başında Jon Elster gelmektedir. "Toplumları birbirine yapısstran, onlarm kaos ve savașa sürüklenerek parçalanmasm engelleyen nedir?" sorusuna The Cement of Society kitabıyla yanıt bulmaya çalsşan Elster, sosyal düzenin temelde iki tip davranış kalıbıyla mümkün olabileceğini ileri sürer: öngörülebilirlik ve işbirliği. Öngörülebilirliğin ve işbirliğinin olmadığı durumlarda kargaşanın kaçınılmaz olduğunu savunan Elster'e göre sosyal düzenin sağlanabilmesi için, bireylerin birbirlerinin davranışlarını tahmin edebiliyor olmaları ve işbirliğine açık olmaları gerekmektedir (Elster, 1989: 
1). Her ne kadar kendisi Uluslararası İlişkiler kuramcısı olmasa da, Elster'in bu yaklaşımı, uluslararası ilişkilere de kolaylıkla uygulanabilir: Devletler arasındaki ilişkilerde öngörülebilirlik ve işbirliğine yatkınlık olduğu müddetçe istikrarlı bir düzenden bahsedilebilir.

Bull ve Elster'in düzen tanımlamaları, istikrarlı bir uluslararası ilişkiler ortamının nasıl sağlanabileceği konusuna yoğunlaşmıştır. Bull ve Elster'in fikirlerinden yola çıkarak, şu şekilde melez bir tanımlama yapılabilir: Devletlerin uluslararası hukuka riayet ettiği, ilişkilerde çatışmasızlığın ve işbirliğinin hâkim olduğu, uluslararası kurum ve kuruluşlar vesilesiyle devletlerin birbirlerinin davranışlarını öngörebildiği uluslararası ortamda, istikrarlı bir düzenden bahsedilebilir.

\subsection{Arktik Bölge'de Düzen: Kargaşa mı, İstikrar mı?}

Bull ve Elster'in fikirlerinden yola çıkarak oluşturulan yukarıdaki tanımlamaya göre, bir uluslararası ilişkiler ortamında istikrarın hâkim olduğu bir düzenden bahsedebilmek için şunlar gereklidir: uluslararası hukuka riayet, çatışmasızlık, işbirliği ve öngörülebilirlik. Arktik Bölge'de hâkim düzenin doğasını tanımlayabilmek için de bu dört faktörün incelenmesi gerekmektedir.

\subsubsection{Arktik Bölge'de Uluslararası Hukuka Riayet ve Çatışmasızlık}

Arktik faaliyetlerin pek çok alanı, başta Birleşmiş Milletler Deniz Hukuku Sözleşmesi (1982), Denizlerin Gemilerden Kirlenmesini Önleme Uluslararası Sözleşmesi (1983), Kutup Ayılarının Korunması Anlaşması (1973) ve diğer çeşitli ikili ve çok taraflı antlaşmalar vasıtasıyla hukukî olarak düzenlenmiştir. Birleşmiş Milletler Deniz Hukuku Sözleşmesi, kı1 devletlerinin Münhasır Ekonomik Bölgeleri'ndeki doğal kaynaklar üzerinde egemenlik haklarına sahip olduklarını, bu hakların, 200 deniz miline kadar uzanan kıta sahanlıkları için de geçerli olduğunu ve derin deniz yataklarındaki maden kaynaklarının ise insanlığın ortak mirası olduğunu belirler. Münhasır Ekonomik Bölgeler'in dişında kalan kaynakların kullanılma sistemi ise 1995 Birleşmiş Milletler Balık Stokları Anlaşması'nda düzenlenen küresel bir rejime tabidir. Uluslararas1 Denizcilik Örgütü de, nakliye ile ilgili bir dizi uluslararası anlaşma geliştirmiştir (Schofield ve Potts, 2008: 154; Hoel, 2009: 100). Görüldüğü üzere Arktik Bölge’deki aktörlerin tüm faaliyet alanları uluslararası hukukla düzenlenmiş, aktörler arası ilişkiler de bu çerçevede istikrarlı bir şekilde sürdürülmektedir.

Soğuk Savaş dönemi boyunca Sovyetler Birliği ve Amerika Birleşik Devletleri'nin güç politikalarının sahnelerinden biri olan Arktika'da (Heininen vd., 2014: 24), Soğuk Savaş sonrası askerî ve siyasî gerilim düşürülebilmiştir (Heininen, 2011: 40). Özellikle 1996 yllında Arktik Konsey'in kurulmasıla birlikte, bölgede işbirliği ve siyasi istikrar ortamı sağlanabilmiştir (Spohr vd., 2013: 14). Buna rağmen, özellikle son on y1llık 
süre içinde, bazı köşe yazılarında ve makalelerde, Arktika'daki çatışmasızlığın ve istikrarın bozulabileceğine dair yorumlar ve spekülasyonlar yayınlanmaktadır. Bu tarz öngörüler, temelde küresel 1sınmaya bağlı olarak bölgeye erişimin kolaylaşması sayesinde, daha çok aktörün bölgede daha etkin olma çabasına gireceği fikrinden yola çıkmaktadır (Koivurova, 2016). Ancak görünürde olan, en azından günümüz ve yakın gelecek için, bölgede uluslararası hukuka sayg1, anlaşmazlıkların hukuk yoluyla çözümü ve dolayısıyla çatışmasızlık ortamının var olduğu ve devam edeceği yönündeki izlenimdir.

\subsubsection{Arktik Bölge'de İşbirliği ve Öngörülebilirlik}

Bir uluslararası sistemde devletlerarası işbirliğini ve devlet davranışlarının öngörülebilirliğini artıracak en önemli etmen, şüphesiz, uluslararası kurum ve kuruluşların varlı̆̆ıdır. Zira uluslararası kurum ve kuruluşların varlı̆̆1, devletlerin birbirlerinin davranışlarını öngörebilmelerini, birbirlerine daha fazla güvenmelerini ve ilişkilerde işbirliğini mümkün kılmaktadır (Oğuzlu, 2015: 160).

Arktik Bölge'de işbirliğinin en önemli platformu, Arktik Konsey'dir. Daha önce de değinildiği üzere Arktik Konsey, 8 üye ülkenin, 6 kalıc1 katılımcı devlet-altı örgütün ve 13 gözlemci devletin faaliyette bulunduğu bir örgüttür. Herhangi bir yaptırım gücü olmasa da, özellikle ekolojik ve sosyolojik konulardaki projeleriyle ve birtakım uluslararası anlaşmaya ön ayak olmasıyla, bölge entegrasyonu ve işbirliği hususlarında önemli bir yere sahiptir. Bölgedeki bir diğer önemli uluslararası örgüt, 1993 yllında kurulan Barents Avrupa-Arktik Konseyi'dir. Barents Avrupa-Arktik Konseyi, Barents Denizi'ne kıyısı bulunan Danimarka, Finlandiya, İzlanda, Norveç, İsveç ve Rusya Federasyonu'nun yanı sira Avrupa Komisyonu'nun da üye olduğu bir örgüttür. Toplantılarını iki senede bir ülkelerin dışişleri bakanları düzeyinde gerçekleştiren örgüt, özellikle ekonomik ve çevresel projelerde işbirliğine odaklanmıştır (Barents Euro-Arctic Region, t.y.). Kuzey Boyutu (Northern Dimension) ise Avrupa Birliği (AB), Rusya Federasyonu, Norveç ve İzlanda'nın oluşturduğu bir işbirliği platformudur. 1999 yllında başlatılan ve 2006 yllında yenilenen bu platformda ABD ve Kanada gözlemci statüsünde yer almaktadır. Çevre, nükleer güvenlik, sağlık, enerji, ulaşım, lojistik, ticaret, yatırım, araştırma, eğitim ve kültür gibi birçok alanda bölgenin refahı, istikrarı ve sürdürülebilir kalkınması için faaliyetler ve projeler yürütmektedir (The Northern Dimension, t.y.). Bölgede etkili bir diğer platform olan Nordik Konsey (Nordic Council), 1952 yllında üye ülkeler ${ }^{10}$ arasında serbest pazar oluşturmak ve üye ülke vatandaşlarının serbest dolaşımını sağlamak amaciyla kurulmuştur. Avrupa Birliği’ne benzer bir yapısı olan Nordik Konsey'in 87 üyeli bir parlamentosu bulunmaktadır.

${ }^{10}$ Nordik Konsey’in üyeleri Danimarka, Finlandiya, İzlanda, İsveç ve Norveç'tir. 
Arktik Bölge'nin en kurumsal uluslararası kuruluşu olan Nordik Konsey, daha çok sosyal ve ekonomik politikalara odaklanmıştır (NORDEN, t.y.).

Bu bilgiler 1şı̆ı̆nda Arktik Bölge'de, uluslararası hukuka riayet edilen, işbirliğinin ön plana çıktığı, bölge özelinde ülkelerin birbirlerinin eylemlerini öngörebildiği ve çatışmasızlık ortamının devam ettiği, istikrarlı bir düzenin hâkim olduğunu söylemek mümkündür. Aynı doğrultuda, bölgede birden çok uluslararası anlaşma, kurum ve kuruluş sayesinde işbirliğinin, çatışmasızlığın ve öngörülebilirliğin hüküm sürdügü tespiti, Arktik Bölge'de işbirliğini konu eden çalışmaların pek çoğunun ortak noktasıdır (Olesen, 2014: 6). Şüphesiz bu, bölgede hiçbir problemin olmadığı yahut yaşanmadığ1 anlamina da gelmemektedir.

Bölgeyle ilgili karamsar çerçeve çizen çalısmalar, bölgede kapsayıcı ve zorlayıcı bir hukukî ve siyasî yapının olmayışının gelecek için tehlike arz ettiği (Borgerson, 2008: 71); bu durumun enerji fiyatlarının yükselmesi ve bölgeye erişimin kolaylaşmasıyla bölge aktörleri arasında 'firtına' kopmasına sebep olabileceği (Graff, 2007: 2); 2007 yllındaki Rus bayrağı krizinin ${ }^{11}$ bölgedeki çıkar çatışmaları odaklı siyasi gerilimin başlangıç noktası olduğu (Young, 2009: 74); Ukrayna'daki gelişmelerin Rusya'nın yayılmacı politika yürütmeye başladığının işaretçisi olduğu ve bu durumun Arktika'da da görülebileceği (Soroka, 2016: 403) konuları etrafinda toplanmıştır. Yine de Arktik Bölge'de anlaşmazlıkların hukuk ya da diyalog yoluyla çözülebildiği istikrarlı bir düzenin ve çatışmasızlı̆ı̆n varlığı konusundaki literatür daha baskındır. Öte yandan, bölgeyle ilgili kötümser yaklaşım sunan yukarıdaki örnekler, 'olan'ları merkeze alan analizlerden ziyade, 'olabilecek'lere odaklanan görüşlerdir. Bu karamsar öngörülere karşı realiteye odaklanan çalışmalarda, örneğin Trenin (2010: 12), 2007'deki bayrak krizinin hukukî bir bağlayıcılığının olmadığını ve krizin ardından Rusya'nın defaatle bölgeyle ilgili politikalarda uluslararası hukuka ve kuruluşlara atıf yaptığını ve eylemleriyle de bunu ispatladığını ifade ederken; Osterud ve Honneland (2014: 176), 'bölgenin doğası'nın devletlerarası rekabet ve çatışma potansiyelini azalttığını savunmaktadır. Bununla birlikte, bölge dışı aktörlerin de Arktika'daki istikrarın devamının taraftarı olduğu, Arktik Konsey'in gözlemci üyelerinden Çin, Japonya ve Güney Kore'nin bölgedeki düzenin devamı için hassas davrandıkları ifade edilmektedir (Moe ve Stokke, 2019: 25). Literatüre 'Arktik İstisnacıllğı' kavramını kazandırdıkları çalışmalarında Exner-Pirot ve Murray (2017), sınırları ve etki alanları bakımından ABD, Rusya ve hatta Çin'in de komşu sayılabileceği, stratejik açıdan oldukça kritik özelliklere sahip Arktika'da

${ }^{11}$ Rusya'nın, Arktik bölgede Norveç'le yaşadığı egemenlik tartışmaları sırasında, kıta sahanlığının 200 deniz mili ötesinde Arktik Okyanus'un dibine Rus bayrağı dikmesinin ardından başlayan tartışma ve konunun hukukî boyutuyla ilgili daha detaylı bilgi için bkz.: Matz-Lück, 2009. 
hüküm süren işbirliği, istikrar ve çatışmasızlık ortamının küre üzerinde bir 'istisna' olduğunu ileri sürmektedir.

Daha önce de ifade edildiği üzere, çalışmanın temel sorunsalı, Arktika'daki uluslararası siyasi düzenin, kuramsal bağlamda en iyi ne şekilde açıklanabileceğini ortaya koymaktır. Bundan önceki bölümlerde Arktik Bölge'deki uluslararası ve bölgesel kurumlar, kuruluşlar, aktörler ve bunların kendi aralarındaki ilişkileri ele alınarak, bölgede istikrarlı bir düzenin hâkim olduğu ortaya çıarılmıştır. Bundan sonraki bölümlerde ise bu düzen hangi teorik yaklaşımla daha iyi açıklanıp anlamlandırılabilir sorusuna cevap aranacaktır.

\subsection{Uluslararası Düzen Çeşitleri ve Arktik Bölge}

Bu noktada, John Ikenberry'nin görüşleri, düzenin doğasını açılama konusunda kolaylık sağlamaktadır. Ikenberry, düzen konusunda Bull ve Elster'den farklı bir bakış açısına sahiptir; uluslararası düzeni "temel kurallar, ilkeleri ve kurumlar olan devletlerarası bir yönetimsel tertip" olarak tanımlar (Ikenberry, 2001: 23). Ikenberry'e göre uluslararası düzenin pek çok farklı versiyonuyla karşılaşılabilir. Uluslararası düzen hem bölgesel hem de küresel ölçekte görülebilir. Bazıları son derece kurumsallaşmışken, bazıları hiyerarşik bir doğaya sahip olabilir. Uluslararası düzen, farklı güç dağılımı ortamlarında da (çok kutuplu, iki kutuplu ya da tek kutuplu düzenlerde) görülebilir. Ikenberry, bu farkl11ıkları kuramsal bir çerçeveye oturtmak maksadıyla, uluslararası düzenin üç farklı şekilde oluşturulabileceğini ifade eder: dengeyle, zorla ya da rizayla. Her tür düzenin kendine has işleyişinin ve mantığının olduğunu belirten Ikenberry, farklı zaman ve mekânlarda bu mekanizmaların en az birinin etrafinda uluslararası düzenin sağlanabileceğini savunur. Dengeye dayalı uluslararası düzen, herhangi bir devletin baskın güç olarak sivrilmediği ortamda, aktörler arasındaki güç dengesi siyasetiyle sürdürülür. Zora dayalı uluslararası düzen, bir hegemon devlet tarafindan sürdürülür ve bu tür bir düzende ülkeler arasındaki ilişkilerde hiyerarşi hâkimdir. Rızaya dayalı düzen ise gücün kurallar ve kurumlar çerçevesinde kullanıldığ1 bir düzen türüdür; bu tür bir düzende devletlerin egemenlik hakları, üzerinde anlaşılan bazı kurallar tarafindan sınırlandırılır ve birtakım ulus-üstü kurumlara devredilir. AB, bu tip bir düzenin ideal örneklerindendir (Ikenberry, 2011: 12-15).

Ikenberry'nin uluslararası düzenle ilgili fikirleri ve üçlü sınıflandırması, şu üç farklı Uluslararası İlişkiler yaklaşımıyla birebir örtüştürülebilir: Çok Kutuplu İstikrar yaklaşımı (dengeye dayalı uluslararası düzen), Hegemonik İstikrar yaklaşımı (zora dayalı uluslararası düzen) ve Demokratik Barış Teorisi (rızaya dayalı uluslararası düzen). Bunlardan ikisi maddi güce ağırlık veren, biri ise ülkelerin rejimlerine odaklanan istikrar yaklaşımlarıdır. Çalışmanın akıcılığı bakımından öncelikle, ülkelerin rejimlerine odaklanan Demokratik Barış Teorisi'ne; ardından maddi güce önem veren ve güç 
siyasetine odaklanan Hegemonik İstikrar ve Çok Kutuplu İstikrar yaklaşımlarına değinilmiştir.

\subsubsection{Yönetimsel Kaynaklı Yaklaşım: Demokratik Barış Teorisi}

Demokratik Barış Teorisi, temelde Immanuel Kant'in fikirlerinden yola çıan, devletlerin iç işlerinde demokratik esaslara göre cumhuriyetçi tarzda yönetilmelerinin uluslararası ilişkilerde barış ve istikrar ortamı yaratacağını iddia eden Cumhuriyetçi Liberalizm ekolüne dayanmaktadır. Bu yaklaşıma göre demokratik devletler arasında savaş çıkma ihtimali, iki sebepten dolayı oldukça düşüktür. Birincisi, demokrasiyle yönetilen ülkelerde uzlaşı, müzakere, işbirliği ve şeffaflık gibi demokratik normlar yerleşmiş ve sindirilmiş olduğu için, bunların diğer devletlerle olan ilişkilerde de olumlu etkiye sebep olduğu düşüncesine dayanır. Demokrasilerde problemler müzakere yoluyla çözülür, kararlar uzlaşı ve ikna etme süreçleriyle ortak bir şekilde alınır. İç işlerinde bu prensiplerle hareket eden demokratik devletler, diğer demokratik devletlerle olan ilişkilerinde de bu prensiplere uyma eğilimi gösterirler. Böyle bir ortamda devletler, aralarındaki sorunları 'güvenlik sorunu' olarak tanımlamaktan ziyade 'politik sorun' olarak tanımlamaya, böylece çözüm bulma sürecinin kolaylaştırılmasına meyillidirler. Başka bir ifadeyle, demokratik ülkeler arasındaki ilişkiler, 'güvenliksizleştirme' prensibine dayanır. Böylelikle demokratik devletler, kendi aralarındaki ilişkilerde uzlaşı, ikna etme, müzakerelerde bulunma, işbirliği ortamları yaratma ve şeffaflık gibi demokratik normlar hâkim olacağı için, birbirleriyle çatışmaya ve savaşa girmezler. Demokratik devletler arasında savaş çıkma ihtimalinin düşük olmasının ikinci temel nedeni, ülkelerin yapısal şartları ile ilgilidir. Demokratik ülkelerde karar alma süreçlerinin şeffaf olması ve yöneticilerin halka hesap verebilir olmaları, bu ülkelerin savaş gibi maliyeti oldukça yüksek kararlar almasını zorlaştıran etmenlerin başında gelir. Demokrasilerde şeffaf karar alma sürecinde sadece siyasi liderler değil, birden çok aktör etkin rol oynar; özellikle kamuoyunun etkisi oldukça yüksektir. Bununla birlikte, tekrar seçilme hedefi olan yöneticilerin radikal kararlar almaktan olabildiğince imtina etmeleri de savaştan kaçınma hususunda önemli bir faktördür. Ayrıca, güçler ayrilığının olduğu demokrasilerde, yasama ve yargi erklerinin yürütme üzerinde frenleyici ve dengeleyici etkilere sahip olmasından dolayı, savaş ilanı ve yurtdışına asker göndermek gibi riski ve maliyeti yüksek kararların uygulanması kolay değildir (Oğuzlu, 2015: 154-156).

Demokratik Barış Teorisi'ne en büyük eleştiriler, doğal olarak Uluslararası İlişkiler disiplininin Realist kanadindan yöneltilmektedir. Demokratik Barış Teorisi'ni bir 'fantezi' olarak gören realistlere göre kalıcı barışın sağlanması mümkün değildir. Çünkü liberal devletler de diğer tüm devletler gibi dış politikasını temelde güç dengesine göre oluşturmaktadır. Realist eleştiriye göre, Demokratik Barış yaklaşımını açıklayabilecek teorik 
bir nedensel mekanizma yoktur; ne demokratik yapilar ne de normlar tarafindan açılanabilir. O halde, teorik olarak açılanamayan demokratik barış olgusu, realistler için yok hükmündedir (Layne, 1994: 5). Demokratik Barış Teorisi'ne yöneltilebilecek bir başka eleştiri, demokratik rejimlerle demokratik olmayan rejimler arasındaki ilişskiler konusunda çok açılamada bulunamamasıdır. Savaşsızlık ve işbirliği ortamının sadece demokratik ülkeler arasında mümkün olabileceğini söyleyen bu yaklaşım, demokratik rejimler ile demokratik olmayan rejimler arasındaki ilişkilerde çatışma ve savaşın yaşanabileceğini belirtmekle yetinmektedir (Oğuzlu, 2015: 156). Yöneltilen tüm eleştirilere rağmen Demokratik Barış Teorisi, Uluslararası İlişkiler disiplininin, özellikle Liberal cenahı tarafindan, genel kabul gören yaklaşımlarından birisidir.

Arktik Bölge özelinde Demokratik Barış Teorisi'nin açıklayıcıllı̆ını test etmek için kullanılabilecek en verimli kaynaklardan biri, The Economist dergisinin yan kuruluşlarından The Economist Intelligence Unit in 2006 yllinda yayınlamaya başladığ1 ve her yıl güncellediği 'Demokrasi Endeksi'dir. Dünya genelindeki 165 ülkenin yönetim biçimlerini beş kategoride ${ }^{12}$ puanlayarak, sonuçları dört tip rejim halinde sıralamaktadır: tam demokrasi, kusurlu demokrasi, melez rejim ve otoriter rejim. Tablo 1'de verilen, Demokrasi Endeksi'nin en güncel hali olan 2018 raporu incelendiğinde, Arktik Bölge ülkeleri özelinde karmaşık bir yapı ortaya çıkmaktadır. Arktik Konsey’e üye 8 üye devletin 6's1, Demokrasi Endeksi'nde ilk 8'dedir; Norveç, İzlanda ve İsveç, sırayla ilk üçü paylaşmıştır. Amerika Birleşik Devletleri, 7.96'lık genel puanıyla 25. sırada iken; Rusya ile diğer yedi Arktik devlet arasında büyük uçurum vardır. 3.24'lük genel puanıla 144. sırada bulunan Rusya Federasyonu, Demokrasi Endeksi'nde 'Otoriter Rejim' olarak tanımlanmıştır.

\section{Tablo 1. Demokrasi Endeksi - 2018}

\begin{tabular}{|c|c|c|c|c|c|c|c|c|}
\hline 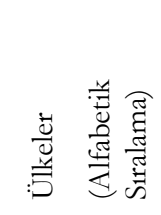 & 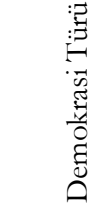 & 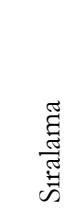 & 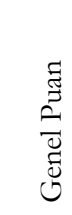 & 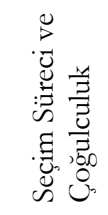 & 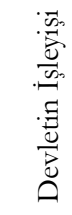 & 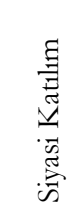 & 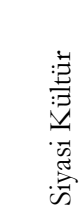 & 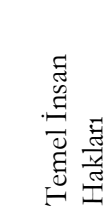 \\
\hline $\mathrm{ABD}$ & K.D.* & 25 & 7.96 & 9.17 & 7.14 & 7.78 & 7.50 & 8.24 \\
\hline Danimarka & T.D.** & 5 & 9.22 & 10.00 & 9.29 & 8.33 & 9.38 & 9.12 \\
\hline Finlandiya & T.D. & 8 & 9.14 & 10.00 & 8.93 & 8.33 & 8.75 & 9.71 \\
\hline
\end{tabular}

$12 \mathrm{Bu}$ kategoriler şunlardır: seçim süreci ve çoğulculuk, devletin işleyişi, siyasi katılım, siyasi kültür ve temel insan hakları. 


\begin{tabular}{|l|l|l|l|l|l|l|l|l|}
\hline İsveç & T.D. & 3 & 9.39 & 9.58 & 9.64 & 8.33 & 10.00 & 9.41 \\
\hline İzlanda & T.D. & 2 & 9.58 & 10.00 & 9.29 & 8.89 & 10.00 & 9.71 \\
\hline Kanada & T.D. & 6 & 9.15 & 9.58 & 9.64 & 7.78 & 8.75 & 10.00 \\
\hline Norveç & T.D. & 1 & 9.87 & 10.00 & 9.64 & 10.0 & 10.00 & 9.71 \\
\hline Rusya & O.R.*** & 144 & 2.94 & 2.17 & 1.79 & 5.00 & 2.50 & 3.24 \\
\hline $\begin{array}{l}* \text { K.D.: Kusurlu Demokrasi } \\
* * *\end{array}$ O.R.: Otoriter Rejim & ** T.D.: Tam Demokrasi \\
\hline
\end{tabular}

Kaynak: The Economist, 2019

Demokratik Barış Teorisi, daha önce de ifade edildiği üzere, sadece demokratik rejimlere sahip ülkeler arasındaki ilişkilerde savaşsızlık ve istikrar ortamının mümkün olabileceğini savunmaktadır. Demokrasi Endeksi'nde Arktik Konsey üyelerinden Rusya Federasyonu ve gözlemcilerinden Çin Halk Cumhuriyeti, otoriter rejim olarak tanımlanmıştır (The Economist, 2019). Bu veriler ışığında, Demokratik Barış Teorisi'nin Arktik Bölge'deki düzeni açıklayamayacağı açıkça ortadadır.

\subsubsection{Güç Merkezli Yaklaşımlar: Hegemonik İstikrar ve Çok Kutuplu İstikrar Yaklaşımları}

\subsection{2.a. Hegemonik İstikrar Yaklaşımı}

Hegemonik İstikrar yaklaşımı, en basit ifadelerle, tek bir ülkenin egemen olduğu bir dünya düzeninin en istikrarlı düzen olacağını savunur (Sachse, 1989: 3). Bu yaklaşıma göre, sadece hegemonik bir güç aracilı̆̆yla, ülkeler arasında ticareti kolaylaştıran ve düzeni bozmaya çalışan ülkeleri cezalandıran, böylece istikrarı sağlayan uluslararası kurallar düzenlenebilir (Yazid, 2015: 68). Hegemonik İstikrar yaklaşımı, güç ve cezalandırma vurgusuyla realist geleneği çağrnştırıyor olsa da, aslında liberal ekonomik düzeni destekleyen bir yaklaşımdır. Örneğin Robert Gilpin (1975: 85), liberal uluslararası ekonominin ancak sistemdeki en güçlü devletin desteğiyle kurulabileceğini ve sürdürülebileceğini savunur (akt. Sachse, 1989: 4). Hegemonik İstikrar yaklaşımına göre hegemon, uluslararası sistemde ortak çıkarları sağlayacağını taahhüt eden varlıklı ve güçlü bir devlettir. Bu ortak ç1karlar, güvenlik ve -ne kadar yaygin olursa o kadar iyi şekilde işleyenserbest ticaret sistemidir. Bunların sağlanması maliyetlidir; ancak hegemon güç, dünya sistemindeki baskın konumu nedeniyle tüm maliyete rağmen en çok kazanan olacaktır; bu sistem geliştikçe hegemon güç daha çok kazanacaktır (Dirzauskaite ve Ilinca, 2017: 34). Bir devletin hegemon güç olabilmesi için sistemdeki tek büyük gücün kendisi olması gerekir. Birden 
fazla büyük gücün sahne aldığ1 bir sistemde hegemonyadan söz edilemez (Godwin, 2004: 82). Bu açıdan 'tek kutupluluk' ile oldukça örtüştügü görülen hegemonik istikrarın farkı, tek kutupluluk gibi sadece küresel düzeyde değil, bölgesel düzeyde de geçerli olabilmesidir. Ayrıca, tek kutuplu sistem genel olarak bir güç dengesi mekanizması iken, hegemonik sistem başat gücün herhangi bir kısıtlama olmaksızın sürekli kapasitesini ve tahakkümünü artırmaya yönelik davranış sergilediği bir ortamdır (Pape, 2005: 11).

Bu aşamada çalışmayla ilgili cevap bekleyen soru şu şekilde sorulabilir: Arktik Bölge'deki istikrarlı uluslararası düzen, Hegemonik İstikrar yaklaşımıyla açıklanabilir mi? Bu sorunun cevabını aramadan önce, bir diğer güç merkezli yaklaşım olan Çok Kutuplu İstikrar yaklaşımını ele almak; ardından bölgedeki güç dengelerini inceleyerek güç merkezli bu iki yaklaşımın bölgedeki düzeni ne ölçüde açıklayabildiklerini tespit etmek daha yerinde olacaktır.

\subsection{2.b. Çok Kutuplu İstikrar Yaklaşımı}

Hegemonik istikrar dönemleri, tarihte görülen bir durum olsa da, istisna olarak kabul edilir. Devletlerin bir kutbun hegemonik hale gelmesinden kaçınmaya çalıştıkları bir güç dengesinin yarattığı istikrar, daha genel ve daha 'normal' bir durumdur (Wegge, 2010: 168). "Güç dengesi” kavram1, Realist kuramla yakından ilişkilidir ve kökenleri Thucydides ve Machiavelli'nin yazılarına dayanan Realist geleneğin kendisi kadar eskidir. Çünkü Realist ekol, uluslararası ilişkilerin tabiatının güç için -ya da güç aracilığıyla ${ }^{13}$ mücadele ve rekabet olduğunu kabul eder.

Her ne kadar Realist ekol, iki kutuplu sistemin çok kutuplu sisteme nazaran daha istikrarlı olduğunu savunsa da (Balc1, 2015: 135), çok kutupluluğun sistemi daha istikrarlı kilan avantajlara sahip olduğunu savunanlar da vardır. Bağımsız aktörlerin sayısındaki artış, sistem içinde işbirliği ve ittifak olanaklarını da artıracaktır. İktidarı ve nüfuzu birbirleriyle paylaşan ne kadar çok devlet varsa, etkileşim için o kadar çok firsat var demektir. Ayrıca devletler, diğer devletlerle ilişkilerinde sadece kendileri açısından değil, ittifakta bulundukları devletleri de hesaba katarak dış politika izleyecekleri için, çatışma olasılıkları da azalacaktır (Deutsch ve Singer, 1964: 392). Bir başka ifadeyle, kendisiyle iyi ilişkiler içinde bulunmasa bile müttefiki ile olan ilişkilerini bozmak istemeyeceğinden dolayı, muhatap olunan devletlere karşı saldırgan ve çatışmacı tutumların sergilenme ihtimali düşecektir. $\mathrm{Bu}$, çok kutuplu sistemde devletlerin karşıllklı bağımlılığının iki kutuplu sisteme kıyasla daha yüksek olduğu anlamına gelir; bu yüzden

\footnotetext{
13 Yapısal Realizm'in iki kolunun (Saldırgan ve Savunmacı) ayrıştı̆̆ı nokta, güç kavramına yaklaşımlarıyla ilgilidir. Savunmacı Realizm'e göre güç, devletin güvenliğini ve bekâsını sağlamak için bir araçtır. Devletlerin güç değil, güvenlik azamileştiricileri olduğu savunur. Saldırgan Realizm'e göre ise güç amaçtır; devletler güç azamileştiricileridir (Mearshimer, 2013: 78).
} 
devletler, sistemdeki diğer devletlerin eylemlerine verdikleri tepkileri dikkatlice düşünmek zorundadırlar. Dahası, ikiden fazla büyük güçle, dünya siyaseti sifir toplamlı bir oyuna sahne olmayacaktır (Rosecrance, 1966: 317). Ayrıca, çok kutuplu sistemde aktörlerin bir ittifaktan diğerine geçmesi daha kolay olacağ için, güç dağılımı daha dengeli bir şekilde olacak, arada uçurumların oluşması önlenebilecektir (Huesken, 2012: 43).

\subsection{2.c. Arktik Bölge'de Güç Dağılımı ve Arktik Düzenin Doğas1}

Güç merkezli istikrar teorilerinin Arktik Bölge'de geçerli olup olmadığını test edebilmek için, bölge aktörleri arasındaki güç dağılımını incelemek gerekmektedir. Güç, tek boyutlu bir olgu değildir; bir devletin toplam gücünü, bazı kapasite ve kabiliyetler belirlemektedir. Bu kapasite ve kabiliyetler, en başta askerî, ekonomik ve teknolojik güçten meydana gelmektedir (Waltz, 1979: 131).

\section{Tablo 2. Güç Kapasitesini Belirleye Başlıca Etkenler}

\begin{tabular}{|l|l|l|l|l|l|}
\hline & $\begin{array}{l}\text { GSMH } \\
\text { (milyar } \\
\text { dolar) }\end{array}$ & $\begin{array}{l}\text { Kişi Başına } \\
\text { Düşen Milli } \\
\text { Gelir (dolar) }\end{array}$ & $\begin{array}{l}\text { Askeri } \\
\text { Harcama } \\
\text { (milyon } \\
\text { dolar) }\end{array}$ & $\begin{array}{l}\text { Küresel } \\
\text { Rekabet } \\
\text { Kapasitesi } \\
\text { (puan } \\
\text { /sıralama) }\end{array}$ & $\begin{array}{l}\text { Teknolojik } \\
\text { Seviye } \\
\text { (dünya } \\
\text { siralamasi) }\end{array}$ \\
\hline ABD & 19400 & 60000 & 597000 & $85 / 1$ & 11 \\
\hline Danimarka & 325 & 56000 & 3700 & $80 / 10$ & 11 \\
\hline Finlandiya & 252 & 45000 & 3500 & $80 / 11$ & 1 \\
\hline İsveç & 538 & 53000 & 5500 & $81 / 9$ & 2 \\
\hline İzlanda & 24 & 70000 & - & $74 / 24$ & - \\
\hline Kanada & 1653 & 45000 & 20000 & $79 / 12$ & 11 \\
\hline Norveç & 399 & 75000 & 6300 & $78 / 16$ & 19 \\
\hline Rusya & 1577 & 10000 & 55000 & $65 / 43$ & 29 \\
\hline
\end{tabular}

Kaynak: Schwab, 2018; Dünya Bankas1, t.y.; SIPRI, 2017; The Economist Intelligence Unit, 2018.

Tablo 2'de, Arktik Bölge ülkeleri arasinda askerî, ekonomik ve teknolojik kapasiteleri bağlamında güç dağılımı özetlenmiştir. Amerika Birleşik Devletleri'nin hem ekonomik hem de askerî kapasite bağlamında diğer ülkelerin oldukça önünde olduğu görülmektedir. Ancak Arktika özelinde diğer parametreler de göz önüne alındığında, durum daha farklı bir şekilde görülmektedir.

$\mathrm{ABD}$ dünyanın en güçlü ekonomisine ve en kompleks askerî gücüne sahip olsa da, maddi ve askerî olanaklarını Arktik Bölge'ye doğru yönlendirmediği için, ABD'nin bölgede hegemon bir güç olduğu söylenemez. ABD'nin kısıtlı buzkıran kapasitesi ${ }^{14}$ bu durumun en açı

14 Rusya'nın 40'ın üzerinde buzkıran gemisine karşın ABD'nin sadece 2 buzkıranı vardır. Buzkıranların Arktik Bölge özelinde önemi hakkında ve Rusya ve ABD'nin buzkıran kapasiteleriyle ilgili detaylı ve güncel bilgiler için bkz.: CRS Report, 2019; Gilmour, 2018. 
örneklerindendir. Arktik Bölge'de en geniş coğrafyaya sahip olması dolayısıyla bölge şartlarına uygun teknolojik kapasitesi oldukça yüksek olan Rusya da, ekonomik koşullarından ötürü herhangi bir hegemonya oluşturmaktan oldukça uzaktır. Öte yandan, Arktik Konsey'in diğer üyeleri, Rusya ve ABD'ye nazaran daha küçük ekonomilere sahip olsalar da, özellikle demokrasi endeksleri, yüksek refah seviyesi ve teknolojik kabiliyetleriyle ön plana çıkmaktadır.

Hegemonik İstikrar yaklaşımını destekleyebilecek, tek bir aktörün başat güç olarak sivrildiği asgarî koşulların sağlanamadığı görülen Arktik Bölge'deki uluslararası düzeni, aktörlerin birbirlerine maddi güç ve kapasiteleri bağlamında üstünlük kurmaktan uzak olduğu ve denge politikasına dayanan Çok Kutuplu İstikrar yaklaşımının açıklayıcı gücü çok daha yüksektir. Zira Arktika'da stratejik açıdan en kritik bölge, hem yeraltı zenginlikleri bakımından hem de yeni ticaret yollarına ev sahipliği yapma bakımından, Arktik Okyanus'tur. Bu açıdan, Arktik Okyanus'a kıyısı bulunan beş ülke (Arktik Beşli), bölgedeki en önemli ülkeler olarak öne çıkmaktadır. ABD'nin bölgeyle ilgili düşük teknolojik kapasitesine rağmen güçlü ekonomisi ve askerî kapasitesiyle; Rusya'nın nispeten zayıf ekonomisi ve yönetimsel zaaflarına rağmen bölgedeki en geniş topraklara sahip olması ve bölgeyle ilgili teknolojisiyle; Danimarka, Norveç ve Kanada'nın ise yüksek refah seviyeleri, teknolojik kapasiteleri ve bölgeyle ilgili uluslararası kurum ve kuruluşlardaki kabiliyetleriyle öne çıktığ1 görülmektedir (Wegge, 2010: 172173). Güç kapasitelerinin dağılımı göz önüne alındığında, Arktik Bölge'de düzen, Arktik Beşli’nin birlikte egemen olduğu, diğer aktörlerin ikincil rol oynadığı, Çok Kutuplu İstikrar yaklaşımıyla açıklanabilmektedir.

\section{Sonuç}

Bull ve Elster'in tanımlamaları bağlamında istikrarın hüküm sürdüğü Arktik Bölge'deki uluslararası düzenin doğasını açıklayabilmek için, Ikenberry'nin üç farklı istikrar yaklaşımından faydalanılmıştır. Ülkelerin rejimlerine odaklanan Demokratik Barış Teorisi, bölgenin önemli aktörlerinden Rusya'nın 'otoriter' rejimi dolayısıyla açılayıcı gücünü kaybetmiştir. Güç dağılımına odaklanan yaklaşımlarda Hegemonik İstikrar yaklaşımı ise, bölgede herhangi bir hegemon güçten bahsedilemeyeceği için uygulanamamıştır. Arktik Okyanus'a kıyısı bulunan beş ülkenin farklı güç kapasiteleriyle öne çıktığı Arktik Bölge'de düzen, en güçlü şekilde Çok Kutuplu İstikrar yaklaşımıyla ile açıklanabilmiştir.

Çok kutuplu sistemde istikrar, uluslararası kurum ve kuruluşların mevcudiyetiyle daha sürdürülebilir bir düzen haline gelmektedir. Birleşmiş Milletler Deniz Hukuku Sözleşmesi başta olmak üzere uluslararası hukuka riayet edilen, Arktik Konsey başta olmak üzere uluslararası kuruluşlar vasıtasıyla işbirliğinin yürütüldüğü, sadece maddi konularla değil ekolojik ve sosyolojik hususlarla da ilgilenilen Arktika'da düzen, sadece güç dengesi 
siyasetiyle değil, karşılıklı müzakere ve işbirliğiyle de sürdürülmektedir. Yeni rotaların kullanımına ve yeraltı kaynaklarının erişimine imkân sağlayan iklim değişikliğine bağlı buzul erimesi, bir yandan müşterek refahı artırabilecek firsatlar yaratırken, öte yandan süreç iyi yönetilemezse sorunlara ve çatışmalara da sebep olabilir. Arktik kaynaklanı müşterek refahın faydasına kullanabilmenin yolu da bölgedeki istikrarlı uluslararas1 düzenin sürdürülmesini sağlamaktan geçmektedir.

Soğuk Savaş'tan sonraki dönemde Arktik Bölge'de hâkim olan çok kutuplu düzen, bölgedeki istikrarın doğası konumundadır. Yaklaşık otuz senelik bu zaman diliminde Arktika, oldukça yüksek -potansiyel- stratejik önemine rağmen, sıcak çatışmalardan uzak bir şekilde, anlaşmazlık ve krizlerin çok az görüldüğü, devletlerin hukuka riayet ettiği ve işbirliği içinde eylemlerde bulunduğu 'istisnaî' bir örnek oluşturmaktadır. Uluslararası hukuka sayg1 ve hükümetlerarası kurumları güçlendirme eğilimine dayanan bu çok kutuplu düzenin, ABD ve Rusya'dan ziyade, nispeten küçük Arktik ülkelerin (Kanada, Danimarka ve Norveç gibi) lehine bir ortam sağladığ1 görülmektedir. Bölgede hâkim olan çok kutuplu düzen sayesinde sadece güçlü ülkeler değil, küçük ülkelerin de kazançlı çıktığı/çıkacağı bir ortam mevcuttur. Arktik Bölge'deki siyasi düzen ve istikrar, sadece bölge ülkelerini ilgilendiren bir konu değildir. Sonuçta, Arktika sadece bölge ülkelerinin değil, tüm kürenin faydalanabileceği ölçekte firsatlar sunmaktadır. 


\section{Kaynakça}

Ahlenius, H. (2007). "Northern Sea Route and the Northwest Passage". https://benmuse.typepad.com/arctic_economics/2008/03/fromrotterdam.html (erişim tarihi: 5 Aralık 2018).

Ahlenius, H., Johnsen, K., ve Nellemann, C. (2005). Vital Arctic Graphics: People and Global Heritage on our Last Wild Shores. UNEP.

Arctic Council. (2018). "The Arctic Council: A Backgrounder". https://arctic-council.org/index.php/en/about-us (erişim tarihi: 2 Aralik 2018).

Arctic Monitoring and Assessment Programme (AMAP). (2010). "Definitions of the Arctic Region". https://www.amap.no/documents/doc/definitions-of-the-arcticregion/248 (erişim tarihi: 2 Aralık 2018).

Axelrod, R. ve Keohane, R. (1985). "Achieving Cooperation under Anarchy: Strategies and Institutions". World Politics, 38(1), 226-254.

Balcı, A. (2015). "Realizm”. Uluslararası Iliş̧kilere Giriş. Ş. Kardaş ve A. Balc1 (ed.). İstanbul: Küre.

Barents Euro-Arctic Region. (t.y.). "Cooperation in the Barents Euro-Arctic Region”. https://www.barentscooperation.org/en/About (erişim tarihi: 5 Aralık 2018).

Bekkers, E., Francois, J., ve Romagosa, H. (2015). Melting Ice Caps and the Economic Impact of Opening the Northern Sea Route. Amsterdam: CPB Netherlands Bureau for Economic Policy Analysis.

Borgerson, S. G. (2008). "Arctic Meltdown: The Economic and Security Implications of Global Warming”. Foreign Affairs, 87, 63-77.

Bull, H. (2002). The Anarchical Society: A Study of Order in World Politics (3. b.). New York: Palgrave.

Conservation of Arctic Flora and Fauna (CAFF). (2013). Arctic Biodiversity Assessment. Stell, Izlanda: Arctic Council.

CRS Report. (2019). “Coast Guard Polar Security Cutter (Polar Icebreaker) Program”. https://fas.org/sgp/crs/weapons/RL34391.pdf (erişim tarihi: 14 May1s 2019).

Desjardins, J. (2016). "The Energy and Mineral Riches of the Arctic". https:/ /www.visualcapitalist.com/energy-and-mineral-riches-ofthe-arctic (erişim tarihi: 5 Aralık 2018).

Deutsch, K., ve Singer, D. (1964). "Multipolar Power Systems and International Stability”. World Politics, 16(3), 390-406. 
Dirzauskaite, G., ve Ilinca, N. (2017). Understanding "Hegemony" in International Relations Theories. Aalborg: Aalborg University.

Duhaime, A., ve Caron, A. (2006). "The Economy of the Circumpolar Arctic". The Economy of the North. S. Glomsrod ve I. Aslaksen (ed.). Oslo: Statistics Norway.

Dünya Bankası. (t.y.). "World Bank Data". https://data.worldbank.org/ (erişim tarihi: 8 Aralık 2018).

Ecorys Research Programme. (2014). Valuating the Arctic Ice Melt. Rotterdam: NEI Foundation.

Elster, J. (1989). The Cement of Society: A Study of Social Order. Cambrigde: University of Cambridge.

Exner-Pirot, H., ve Murray, R. (2017). Regional Order in the Arctic: Negotiated Exceptionalism. Politik, 20(3), 47-64.

Gilmour, J. G. (2018). "Icebreaker Operations in the Arctic Ocean”. Journal of Military and Strategic Studies, 18(3), 16-30.

Gilpin, R. (1975). U.S. Power and the Multinational Corporation. New York: Basic Books.

Godwin, P. H. (2004). "China as Regional Hegemon". The Asia-Pacific: A Region in Transition. J. Rofle (ed.). Honolulu: Asia-Pacific Center for Security Studies.

Graff, J. (2007). "Fight for the Top of the World". http://content.time.com/time/magazine/article/0,9171,1663848,0 0.html (erişim tarihi: 11 Aralık 2018).

Heininen, L. (2011). "The end of the post-Cold War in the Arctic". Nordia Geographical Publications, 40(4), 31-42.

Heininen, L., Sergunin, A., ve Yarovoy, G. (2014). Russian Strategies in the Arctic. Moskova: Valdai Discussion Club.

Heleniak, T. (2014). "Arctic Populations and Migration". Arctic Human Development Report: Regional Processes and Global Linkages. J. Larsen ve G. Fondahl (ed.). Kopenhag: Nordic Council of Ministers.

Hoel, A. H. (2009). "The High North Legal-Political Regime". Security Prospects in the High North. S. Holtsmark ve B. Smith-Windsor (ed.). Roma: NATO Defense College (NDC).

Huesken, F. W. (2012). "International Systems, Polarity, Cybertechnology and Security". Synesis: A Journal of Science, Technology, Ethics, and Policy, 3(1), 40-51. 
Ikenberry, J. (2001). After Victory: Institutions, Strategic Restraint, and the Rebuilding of Order After Major W ars. Princeton: Princeton University Press.

Ikenberry, J. (2011). Liberal Leviathan: The Origins, Crisis, and Transformation of American World Order. Princeton: Princeton University Press.

Jervis, R. (2016). “The $\$ 5.4$ billion HOV lane: Will Panama Canal expansion boost global trade?". https://www.usatoday.com/story/news/2016/06/23/panamacanal-expansion-slump/86279016/ (erişim tarihi: 5 Aralık 2018).

Jorgensen, F. A. E. (2015). "İngiliz Okulu”. Uluslararası İliş̧kilere Giriş. Ş. Kardaş ve A. Balc1 (ed.). İstanbul: Küre.

Kavka, G. (1983). “Hobbes's War of All Against All”. Ethics, 93(2), 291-310.

Koivurova, T. (2016). "Analysis: The Arctic Conflict - Truth, Fantasy or a Little bit of Both?” https://www.highnorthnews.com/en/analysisarctic-conflict-truth-fantasy-or-little-bit-both (erişim tarihi: 5 Aralık 2018).

Kuersten, A. (2016). "The Arctic Five versus the Arctic Council". Arctic Yearbook 2016. L. Heininen, H. Exner-Pirot ve J. Plouffe (ed.). Akureyri, İzlanda: Northern Research Forum.

Layne, C. (1994). "Kant or Cant: The Myth of the Democratic Peace". International Security, 19(2), 5-49.

Lindholt, L. (2006). "Arctic Natural Resources in a Global Perspective". The Economy of the North. S. Glomsrød ve I. Aslaksen (ed.). Oslo: Statistics Norway.

Matz-Lück, N. (2009). "Planting the Flag in Arctic Waters: Russia's Claim to the North Pole". Göttingen Journal of International Law, 1(2), 235-255.

Mearshimer, J. J. (2013). "Structural Realism". International Relations Theories: Discipline and Diversity. T. Dunne, M. Kurki, ve S. Smith (ed.). Oxford: Oxford University Press.

Moe, A. ve Stokke, O. S. (2019). "Asian Countries and Arctic Shipping: Policies, Interests and Footprints on Governance". Arctic Review on Law and Politics, 10, 24-52.

Mundy, M. (2016). “The Polar Express Lane: Promoting Cleaner Shipping in The Northwest Passage". The Georgetown Environmental Law Review, 29(153), 153-183. 
Nong, D., Countryman, A., Warziniack, T., ve Grey, E. (2018). “Arctic Sea Routes: Potential New Pathways for Nonindigenous Species Spread". Arctic, 71(3), 269-280.

NORDEN. (t.y.). "The Nordic Council". https://www.norden.org/en/information/nordic-council (erişim tarihi: 5 Aralık 2018).

Oğuzlu, T. (2015). “Liberalizm”. Uluslararası Iliş̧kilere Giriș. Ş. Kardaş ve A. Balc1 (ed.). İstanbul: Küre.

Olesen, M. R. (2014). Cooperation or conflict in the Arctic: A Literature Review (DIIS Working Paper 2014:08). Kopenhag: Danish Institute for International Studies.

Osterud, O. ve Honneland, G. (2014). "Geopolitics and International Governance in the Arctic". Arctic Review on Law and Politics, 5(2), 156-176.

Pape, R. A. (2005). "Soft Balancing against the United States". International Security, (23), 7-45.

Perry, C., ve Andersen, B. (2012). New Strategic Dynamics in the Arctic Region. Cambridge: The Institute for Foreign Policy Analysis.

Rosecrance, R. N. (1966). "Bipolarity, Multipolarity, and the Future". The Journal of Conflict Resolution, 10(3), 314-327.

Ross, J. E. (2014). "Global Warning: The Arctic Meltdown". Ocean Graphic Magazine, 30(10), 97-164.

Sachse, V. E. (1989). Hegemonic Stability Theory: An Examination. Baton Rouge, Louisiana: Louisiana State University.

Schofield, C., ve Potts, T. (2008). "Current Legal Developments: The Arctic". International Journal of Marine and Coastal Law, 23(1), 151176.

Schwab, K. (2018). Global Competitiveness Report 2018. Cenevre: World Economic Forum.

SIPRI. (2017). "SIPRI Military Expenditure Database". https://www.sipri.org/databases/milex (erişim tarihi: 8 Aralık 2018).

Soroka, G. (2016). "The Political Economy of Russia's Reimagined Arctic”. Arctic Yearbook 2016. L. Heininen, H. Exner-Pirot ve J. Plouffe (ed.). Akureyri, İzlanda: Northern Research Forum. 
Spohr, A., Höring, J., Cerioli, L., Lersch, B., ve Soares, J. (2013)." The Militarization of the Arctic: Political, Economic and Climate Challenges". UFRGSMUN Journal, 11-70.

The Economist. (2019). Democracy Index 2018: Me too?. The Economist Intelligence Unit Ltd.

The Economist Intelligence Unit. (2018). Technological Readiness Ranking. The Economist Intelligence Unit.

The Northern Dimension. (t.y.). "Exploring the Northern Dimension". http://www.northerndimension.info/northern-dimension erişim tarihi: 5 Aralı 2018).

Trenin, D. (2010). "The Arctic: A Front for Cooperation Not Competition”. The Arctic: A View from Moscow. Trenin, D. ve Baev, P. K. (ed.). Washington: Carnegie Endowment for International Peace.

Türk Dil Kurumu (TDK). (t.y.). "Güncel Türkçe Sözlük”. http://www.tdk.gov.tr/index.php?option=com_gts\&kelime $=\mathrm{D} \%$ C3\%9CZEN (erişim tarihi: 2 Aralık 2018).

Waltz, K. (1979). Theory of International Politics. New York: McGraw-Hill.

Wegge, N. (2010). "The Political Order in the Arctic: Power Structures, Regimes and Influence”. Polar Record, 47(241), 165-176.

Yazid, N. M. (2015). "The Theory of Hegemonic Stability, Hegemonic Power and International Political Economic Stability". Global Journal of Political Science and Administration, 3(6), 67-79.

Young, O. R. (2009). "Whither the Arctic? Conflict or Cooperation in the Circumpolar North". Polar Record, 45(232): 73-82. 